\title{
Does Double Electron Capture Lead to the Formation of Biradicals? An ECD-SORI-CID Study on Lacticin 481
}

\author{
Anne J. Kleinnijenhuis* and Albert J. R. Heck \\ Department of Biomolecular Mass Spectrometry, Bijvoet Center for Biomolecular Research and Utrecht \\ Institute for Pharmaceutical Sciences, Utrecht University, Utrecht, The Netherlands
}

\author{
Marc C. Duursma and Ron M. A. Heeren ${ }^{+}$ \\ FOM Institute for Atomic and Molecular Physics (AMOLF), Amsterdam, The Netherlands
}

We studied lacticin 481, a small lantibiotic with three lanthionine bridges, by electron capture dissociation (ECD) in a Fourier transform ion cyclotron resonance (FTICR) mass spectrometer. Following electron capture, very little fragmentation was observed, but species formed by nondissociative single and multiple electron capture were abundant. Ions formed by double electron capture were subjected to sustained off resonance irradiation collision induced dissociation (SORI-CID) to determine whether stable biradicals were formed. In the SORI-CID spectra of the ions formed by double electron capture, some, but minor, $\mathrm{H}^{\bullet}$ radical loss was observed, which was not observed at all for regularly protonated ions. A small part of the ions formed by double electron capture are thus long-lived biradicals. Apart from the observed $\mathrm{H}^{*}$ loss, the SORI-CID spectra of ions that captured two electrons was similar to that of regularly protonated ions and quite different from the SORI-CID spectra of radical ions formed by single electron capture. This implies that recombination of the two radical sites is the dominant process in biradical lacticin 481 ions, at least on the time scale of our SORI-CID experiments. (J Am Soc Mass Spectrom 2005, 16, 1595-1601) (c) 2005 American Society for Mass Spectrometry

$\mathrm{L}$ antibiotics are currently used as preservatives in the food industry, but have the potential to become a new generation of antibiotics [1]. The development of new antibiotics is driven by the fact that (multi-) resistant bacteria are becoming a huge problem for public health. Characteristic of lantibiotics is that they contain lanthionine bridges consisting of a thioether bond that intramolecularly links different parts of the peptide backbone. To study the mechanism of action of lantibiotics on the molecular level, it is important to perform structural analysis. Traditionally, Edman degradation $[2,3]$ has been used for peptide sequencing. With lantibiotics, however, Edman degradation can only be used to sequence the peptides from the termini until the lanthionine bridges that are closest to the termini. Lantibiotics have to be chemically modified to open the lanthionine bridges [4] to complete the

Published online August 11, 2005

Address reprint requests to Professor R. M. A. Heeren, FOM Institute for Atomic and Molecular Physics (AMOLF) Kruislaan 407, 1098 SJ Amsterdam, The Netherlands. E-mail: heeren@amolf.nl

* Also at the FOM Institute for Atomic and Molecular Physics (AMOLF), Kruislaan 407, 1098 SJ Amsterdam, The Netherlands.

${ }^{+}$Also at the Department of Biomolecular Mass Spectrometry, Bijvoet Center for Biomolecular Research and Utrecht Institute for Pharmaceutical Sciences, Utrecht University, Sorbonnelaan 16, 3584 CA Utrecht, The Netherlands.
Edman degradation. Nuclear magnetic resonance (NMR) spectroscopy can be performed on unmodified lantibiotics to retrieve information about the localization of the lanthionine bridges, but in general it is a time-consuming and insensitive analytical technique. Recently we showed that electron capture dissociation (ECD) is a specific method to rapidly localize lanthionine bridges in lantibiotics [5].

In ECD, [6, 7] multiply charged cations are irradiated with low-energy electrons to form radical cations. A part of these ions undergoes very fast fragmentation reactions before the 4-7 eV energy, [8] released by neutralization of a proton, is fully randomized [9]. Therefore, in the case of peptides and proteins, ECD results mainly in the formation of $\mathrm{c}$ and $\mathrm{z}^{\bullet}$ ions $[6,10]$. ECD has been particularly useful in the analysis of even labile post-translational modifications. Fragments often retain their modifications in this fast dissociative process, in contrast to, for instance, collision induced dissociation (CID). The successful application of ECD has been demonstrated, e.g., in the analysis of methionine oxidation [11], O- and N-glycosylation [12, 13], phosphorylation [14], sulfation [15], and carboxylation of peptides and proteins [15].

In the analysis of peptides containing disulfide bonds, ECD is a powerful fragmentation method. When 


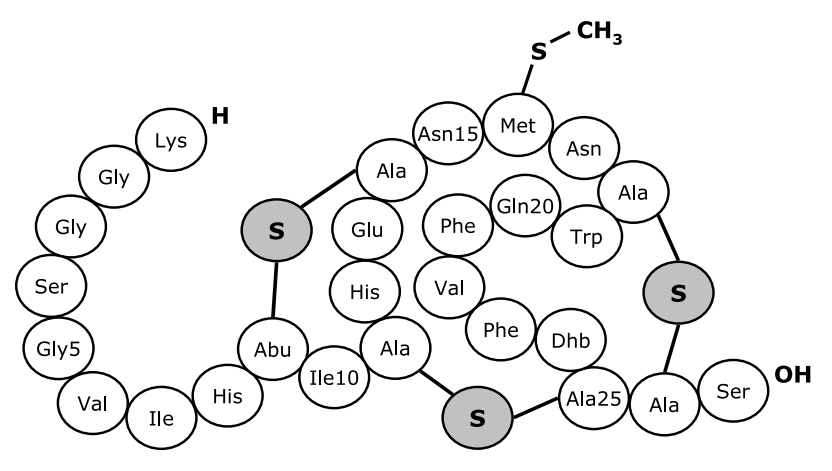

Figure 1. Chemical structure of lacticin 481. Abu is 2-aminobutyric acid and Dhb is dehydroamino-2-butyric acid.

peptide ions containing disulfide bonds are subjected to ECD $[7,16,17]$, predominantly the $S-S$ bond becomes cleaved first. Single electron capture can cleave both the disulfide bond and a backbone bond leading to fragmentation localized near the disulfide bond [7]. This has been rationalized by the fact that disulfide bonds have a very high $\mathrm{H}^{\bullet}$ affinity. In complementary CID experiments, no such specific disulfide bond cleavages could be observed. In a theoretical study performed by Uggerud [18], it was suggested that the most plausible scenarios leading to the specific disulfide bond cleavages are either direct addition of a free hydrogen radical to the disulfide bond or addition of an electron to a disulfide bond in hydrogen-bonded contact with a proton. In the latter scenario an $\mathrm{H}^{\bullet}$ radical is formed close to the disulfide bond. The conformation of the ions determines which scenario is predominant [7]. In another theoretical study it has been stated [19] that the electron capture induced disulfide bond cleavage is less specific than often claimed. Radicals with a hydrogen radical attached to a sulfur atom in the disulfide bond dissociated by cleavages of adjacent $S-H, S-C$, and $S-S$ bonds. Hydrogen atom capture by the disulfide bond in the studied molecule was calculated to be substantially exothermic, explaining the high $\mathrm{H}^{\bullet}$ affinity of disulfide bonds [19]. More detailed information on general ECD mechanisms can be found in a recent paper by Syrstad and Turecek [20].

Although electron capture induced dissociation can lead to extensive peptide sequence coverage, products may also arise from reduction, without subsequent dissociation [21]. These nondissociative products are particularly dominant in the ECD spectra of larger proteins [22], but also appeared to be dominant in the ECD spectra of $<3.5 \mathrm{kDa}$ lantibiotics [5]. Somehow, lantibiotics produce very stable nondissociative radicals when they are irradiated with low-energy electrons. This effect was strongest for the lantibiotic lacticin 481 (Figure 1). This lantibiotic exhibits bactericidal activity against a wide range of gram-positive bacteria and is produced by Lactococcus lactis. Lacticin 481 contains three lanthionine bridges (Scheme 1) that link overlapping parts of the backbone. The precise locations of the lanthionine bridges were elucidated by van den Hooven et al. [23] by a combination of peptide chemistry, mass spectrometry, and NMR spectroscopy. Lacticin 481 displays hardly any ECD fragmentation, hampering the localization of its lanthionine bridges with mass spectrometry. We focus this study on the nondissociative species of lacticin 481 , especially on the ions formed by double electron capture. There are two possibilities in the case of a multiply protonated ion capturing two electrons: the induced radical sites could recombine to form a new two-electron pair, or they will not recombine and two fixed or mobile radical sites will remain present in the ion. The main purpose of this study is to investigate which of these two scenarios is predominant. Because of the observed specificity of ECD for $\mathrm{S}-\mathrm{C}$ bond cleavage, we expect that the radical sites in lacticin 481 are mainly localized around the lanthionine bridges. We compare the sustained off resonance irradiation collision induced dissociation (SORI-CID) spectra of protonated lacticin 481 ions not exposed to electrons to the SORI-CID spectra of the ions that had captured one or two electrons and did not dissociate. The SORI-CID spectra of the species formed by double electron capture are very distinct from those of the species that captured one electron, and show quite some resemblance with the SORI-CID spectra of regularly protonated lacticin 481 ions.

\section{Experimental}

The fragmentation of protonated lacticin 481 ions was studied with three different fragmentation techniques, namely SORI-CID [24, 25],äECD,äandäECDäfollowedäby SORI-CID in a Fourier transform ion cyclotron resonance (FTICR) mass spectrometer. The FTICR instrument was a modified Bruker-Spectrospin (Fällanden, Switzerland) Apex 7.0e, equipped with a 7 tesla superconducting magnet. The experiments were performed using an infinity cell. The electron gun was an indirectly heated barium-tungsten dispenser cathode (TB-198, HeatWave Labs Inc., Watsonville, CA) placed inside the magnet $\sim 30 \mathrm{~cm}$ behind the cell. Just in front of the
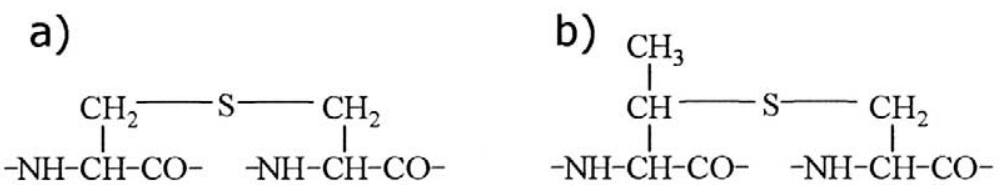

Scheme 1. Chemical structure of (a) lanthionine and (b) 3-methyllanthionine. The N-terminal lanthionine bridge in lacticin 481 has Structure b, the other two bridges have Structure a. 
surface of the cathode a copper control grid is positioned. The cathode was operated using a current of $1.85 \mathrm{~A}$ and a potential of $7.9 \mathrm{~V}$, yielding a power of 14.6 W. Lacticin 481 and mellitin $(15 \mu \mathrm{M})$ were sprayed from a methanol:water:acetic acid 69:29:2 solution with a flow rate of $10 \mu \mathrm{L} / \mathrm{h}$ and a voltage of $3 \mathrm{kV}$ was applied on the spray needle (PicoTip Emitter, New Objective Inc., Woburn, MA) to perform electrospray ionization. After isolation of the ions of interest, they were exposed to low-energy electrons for $5 \mathrm{~s}$. A long irradiation time was required to get sufficient electron capture with lacticin 481 ions. This could have been partly due to bad overlap between the ion cloud and the electron beam. However, we observed that the capture cross section of lacticin 481 ions is substantially lower than that of linear peptide ions of the same charge state and similar mass (i.e., mellitin). During the irradiation time the grid potential was pulsed from $-100 \mathrm{~V}$ to $80 \mathrm{~V}$ and the cathode surface potential from $25 \mathrm{~V}$ to $-1.35 \mathrm{~V}$. The trapping plates were held at a potential of $1 \mathrm{~V}$. Reduced species were isolated again before they were subjected to SORI-CID at a frequency $1500 \mathrm{~Hz}$ away from the resonance frequency of the ion of interest. Argon was used for gas assisted dynamic trapping and as the collision gas. During detection, the pressure in the ICR cell was less than $10^{-9}$ mbar. Data acquisition was performed using in-house developed software and hardwareä[26].

\section{Results}

To illustrate the predominance of nondissociative electron capture with ECD of protonated lacticin ions, we compared the ECD spectra of the $[\mathrm{M}+4 \mathrm{H}]^{4+}$ ions of lacticin 481 and mellitin, which has similar size but is a regular linear peptide. The $[\mathrm{M}+4 \mathrm{H}]^{4+}$ ions of both mellitin and lacticin 481 were isolated and subsequently subjected to ECD using identical experimental conditions. The ECD spectra of mellitin and lacticin 481 are shownänäFigureä2aäandäb,ärespectively.äTheädifferences are obvious in that the reduced ions of lacticin 481 hardly fragment, whereas the reduced ions of mellitin fragment extensively under the same conditions. This means that the reduced lacticin 481 ions are much more stable than the reduced mellitin ions. We reported before that also other lantibiotics produce very stable reducedäpeciesäfterälectronäcaptureą[5].äWeättributed this behavior to the multiple internal lanthionine bridges that are present in lantibiotics. Whereas mellitin is a regular linear peptide and one cleavage will lead to fragmentation, lantibiotics contain several regions where one or two lanthionine bridges link different parts of the backbone. One cleavage in these regions will not lead to detectable fragmentation.

A main aim of the experiments performed in this study was to find out whether long-lived biradicals are formed after double electron capture. Therefore the SORI-CID spectra of lacticin 481 ions formed from [M + $4 \mathrm{H}]^{4+}$ ions by single and double electron capture and regular triply protonated lacticin 481 ions were comparedä(Figureä3).

First, $[\mathrm{M}+4 \mathrm{H}]^{3+}$ ions formed by single electron capture of $[\mathrm{M}+4 \mathrm{H}]^{4+}$ ions were fragmented using SORI-CIDä(Figureä3a).äTheälossäofäanäSH ${ }^{\bullet a ̈}$ radicaläwas the most predominant fragmentation channel. Part of the observed $\mathrm{SH}^{\bullet}$ loss must have originated from the C-terminal lanthionine bridge (Ala18-Ala26), because when, subsequently, SORI-CID was applied on the [M $+3 \mathrm{H}-\mathrm{S}]^{3+}$ ions formed by $\mathrm{SH}^{\bullet}$ loss from $[\mathrm{M}+4 \mathrm{H}]^{3+}$ • ions, this resulted in the formation of $b_{25}^{3+}$ ions without the sulfur atom of the C-terminal lanthionine bridge (results not shown). Additionally, the SORI-CID spectra of $[\mathrm{M}+4 \mathrm{H}]^{3+} \cdot$ ions revealed $\mathrm{H}^{\bullet}$ loss. Very typical in the SORI-CID spectra of $[\mathrm{M}+4 \mathrm{H}]^{3+}$ ions was an extensive series of small neutral losses. The losses of 47 , 59 , and $61 \mathrm{Da}$ could be attributed to $\mathrm{CH}_{3} \mathrm{~S}^{\bullet}, \mathrm{C}_{2} \mathrm{H}_{3} \mathrm{~S}^{\bullet}$, and $\mathrm{C}_{2} \mathrm{H}_{5} \mathrm{~S}^{\bullet}$ loss, respectively, indicating that the $[\mathrm{M}+$ $4 \mathrm{H}]^{3+}$ ions have several fragmentation channels available to lose a radical. Also even-electron losses were observed, namely the losses of 74 and 131 mass units, corresponding to $\mathrm{C}_{3} \mathrm{H}_{6} \mathrm{~S}$ (the side-chain of methionine) and the loss of the side-chain of tryptophan. These electron capture induced side-chain losses have been

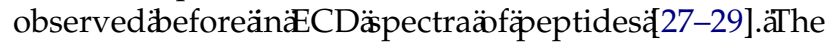
mentioned sulfur-containing neutral losses either originate from the methionine residue or from a lanthionine bridge. To eliminate these neutrals from a lanthionine bridge, two bonds have to be broken, of which at least one is a $\mathrm{C}-\mathrm{C}$ bond. To form these neutrals from the side-chain of methionine only a single cleavage is required, making this scenario more likely. Hence, we attribute these neutral losses to dissociations in the methionine residue. Interestingly, the spectra also displayed peaks $32.978 \mathrm{Da}$ lower in mass than the peaks corresponding to the radical ions formed by nonradical tryptophan and methionine side-chain losses from [M $+4 \mathrm{H}]^{3+}$ ions. These fragment species are thus able to subsequently eliminate an $\mathrm{SH}^{\circ}$ radical. Finally, two different $y$-ions were observed, namely $\mathrm{y}_{25}$ as a $2+$ and $\mathrm{y}_{26}$ both as a $2+$ and a $3+$. The $\mathrm{y}$-ions were $2 \mathrm{Da}$ heavier than normal y ions. For comparison, also SORI-CID spectra of lacticin $481[\mathrm{M}+3 \mathrm{H}]^{2+}$ ions formed by single electron capture of $[\mathrm{M}+3 \mathrm{H}]^{3+}$ ions was measured, but this did not lead to the formation of many fragment ions (results not shown). Very prominent was the small neutral loss of $33 \mathrm{Da}$, which again is assigned to $\mathrm{SH}^{\bullet}$ loss. $\mathrm{H}^{\bullet}$ loss was not observed, so the radical is preferentially eliminated from the radical cation in the form of an $\mathrm{SH}^{\bullet}$ radical.

Next, we evaluated the SORI-CID fragmentation of regularlyä protonatedä [Mä + ä $3 \mathrm{H}]^{3+a ̈}$ ionsä (Figureä3b), which was very different from the SORI-CID fragmentation of $[\mathrm{M}+4 \mathrm{H}]^{3+}$ ions and $[\mathrm{M}+3 \mathrm{H}]^{2+}{ }^{\bullet}$ ions. Under exactly the same conditions, $[\mathrm{M}+3 \mathrm{H}]^{3+}$ ions showed only $\mathrm{NH}_{3}$ and $\mathrm{H}_{2} \mathrm{O}$ small molecule losses and additionally, $z_{26}^{3+}, y_{26}^{2+}$, and $b_{26}^{3+}$ fragment ions. The combined loss of $\mathrm{NH}_{3}$ and $\mathrm{H}_{2} \mathrm{O}$ gives a peak $35 \mathrm{Da}$ lower in mass than the parent ion. The same type of CID 

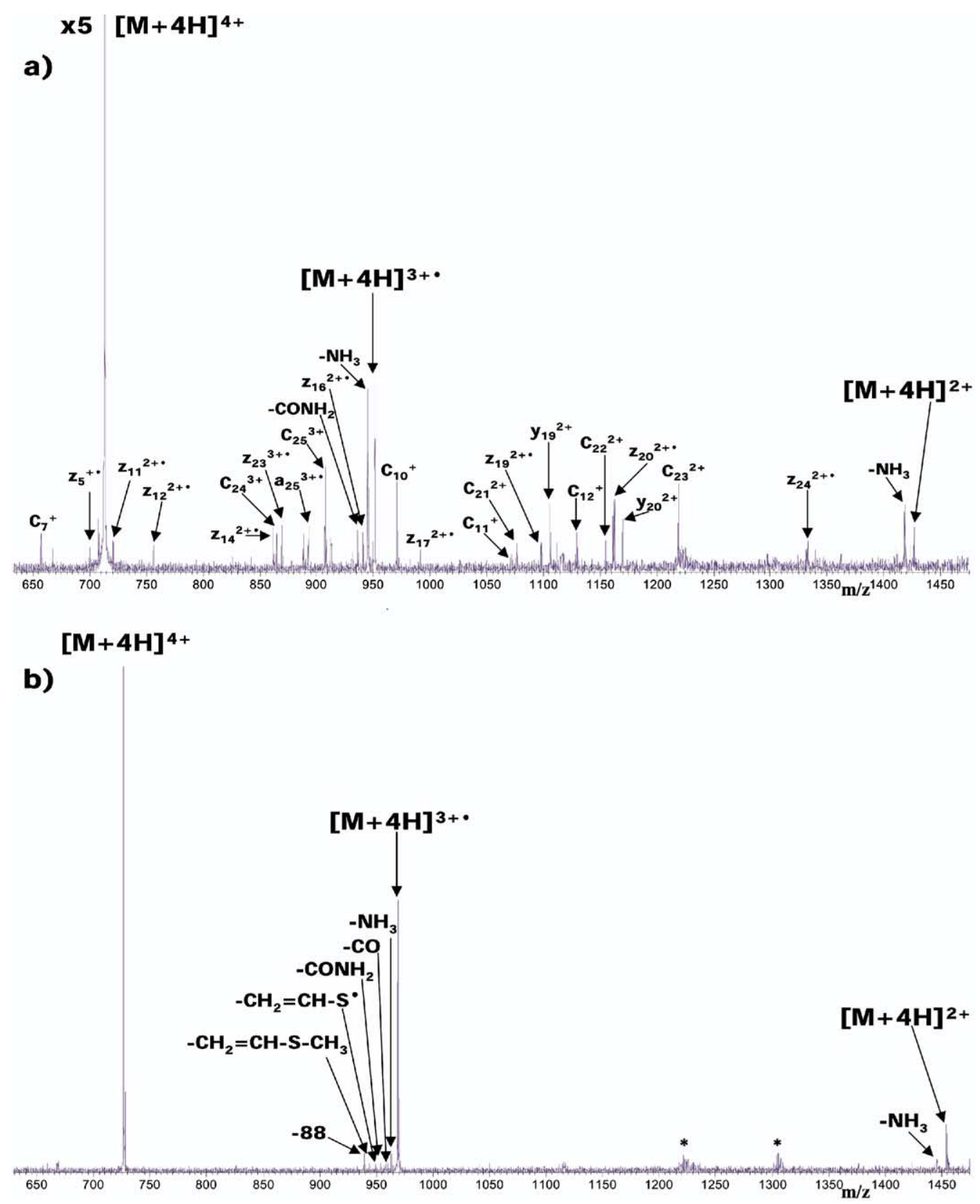

Figure 2. (a) ECD spectrum of mellitin $[\mathrm{M}+4 \mathrm{H}]^{4+}$ ions. The spectrum displays a wide variety of abundant electron capture induced fragment ions. (b) ECD spectrum of lacticin $481[\mathrm{M}+4 \mathrm{H}]^{4+}$ ions with high intensity nondissociated reduced product ions, formed by single and double electron capture. Noise peaks are marked with asterisks.

cleavages were observed for lacticin $481[\mathrm{M}+2 \mathrm{H}]^{2+}$ and $[\mathrm{M}+4 \mathrm{H}]^{4+}$ ions (data not shown). There were no peaks in the CID spectra that could be assigned to $\mathrm{H}^{\bullet}$ loss, $\mathrm{SH}^{\bullet}$ loss, losses from the lanthionine bridges or from the side-chain of methionine or tryptophan. The absence of such fragmentations was expected, as the [M $+3 \mathrm{H}]^{3+}$ ions have no radical character.

From lacticin $481[\mathrm{M}+4 \mathrm{H}]^{4+}$ ions also $[\mathrm{M}+4 \mathrm{H}]^{2+}$ ions were produced via double electron capture. The double electron capture could either induce two separate stable radical sites in the resulting ions or the two radical sites could recombine to form a new chemical two-electron bond. To investigate the nature of the [M $+4 \mathrm{H}]^{2+}$ ions, we subjected them also to SORI-CID (Figureä3c).äRemarkably,ätheseäspectraäshowedäquite some resemblance with the SORI-CID spectra of [M + $3 \mathrm{H}]^{3+}$ ions. Quite intense is the loss of $\mathrm{NH}_{3}$ and $\mathrm{H}_{2} \mathrm{O}$, and furthermore, $\mathrm{y}_{25}^{2+}, \mathrm{y}_{26}^{2+}$, and $\mathrm{z}_{26}^{2+}$ ions are present in the spectra. The formed y ions were both $2 \mathrm{Da}$ heavier than normal y ions. Similar as in the SORI-CID spectra of $[\mathrm{M}+3 \mathrm{H}]^{3+}$ ions, a loss of $34 \mathrm{Da}$ was present, which corresponds to two $\mathrm{NH}_{3}$ losses. At higher collision energies, also a 35 Da loss appeared, which corresponds to a combined $\mathrm{NH}_{3} / \mathrm{H}_{2} \mathrm{O}$ loss. Interestingly, there is no 
a)

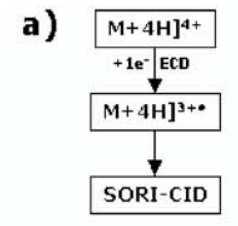

$\left[(\mathrm{M}+4 \mathrm{H})^{3+\bullet-S H \cdot}\right]^{3+}$
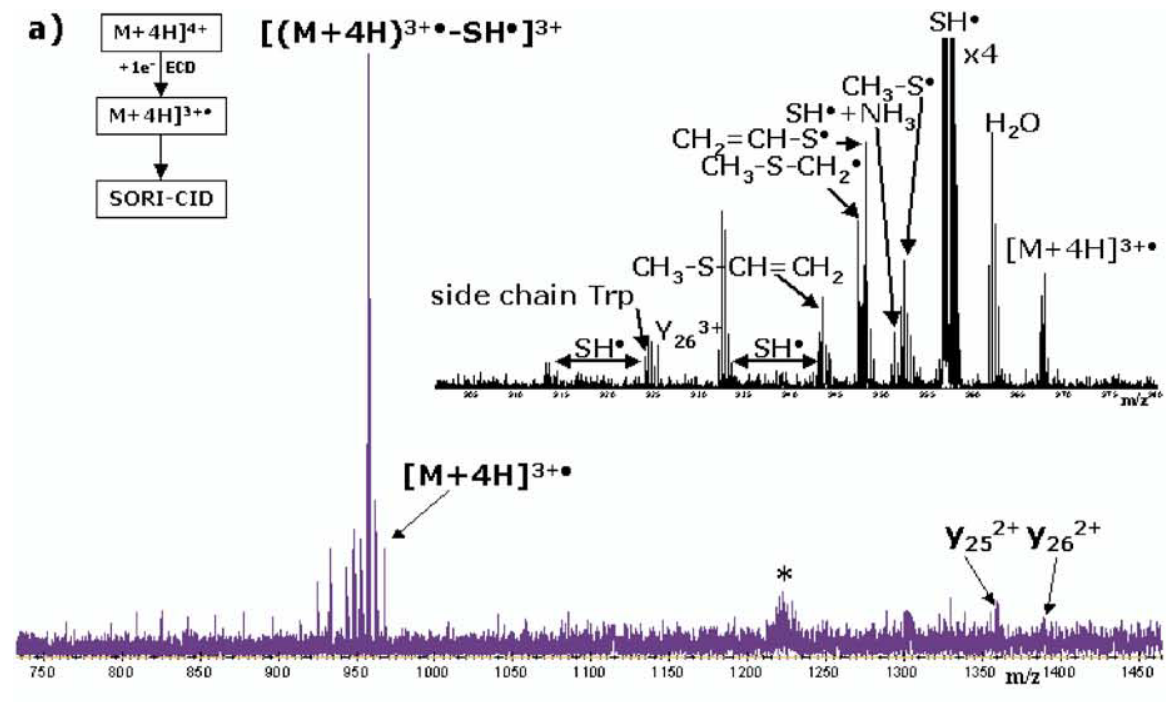

b) $\frac{\mathrm{M}+3 \mathrm{H}]^{3+}}{\square}$

side chain Trp

$[\mathrm{M}+3 \mathrm{H}]^{3+}$

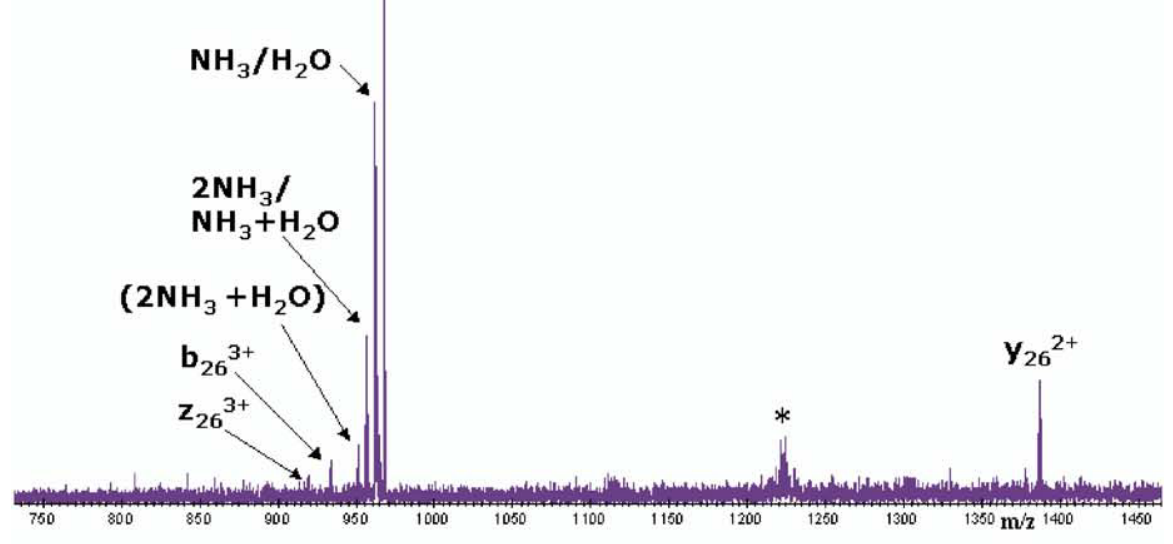

c)
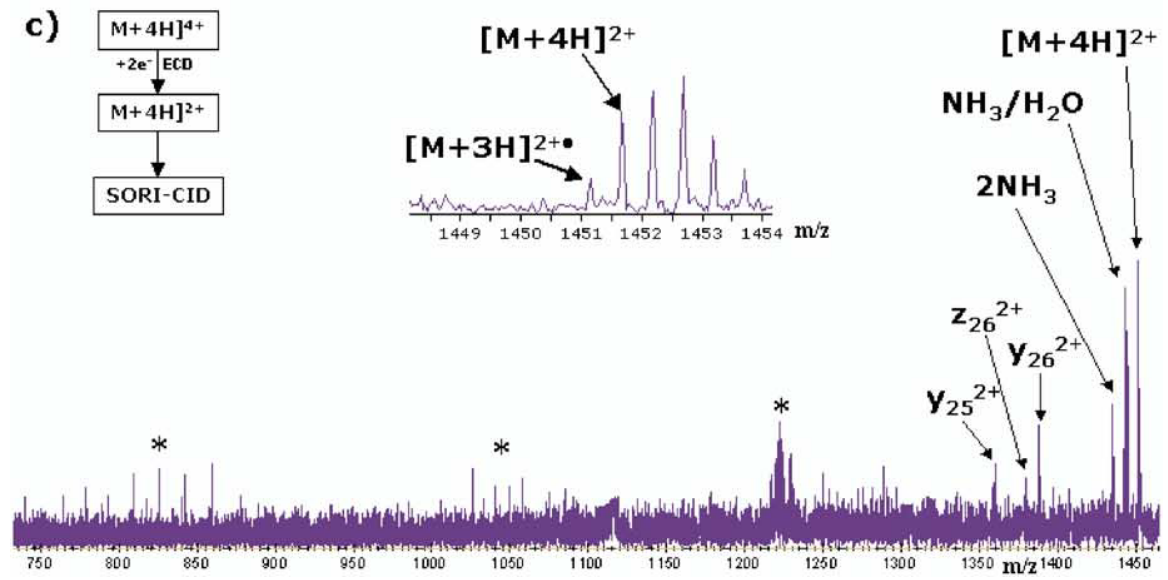

Figure 3. (a) SORI-CID spectrum of lacticin $481[\mathrm{M}+4 \mathrm{H}]^{3+} \bullet$ ions formed by single electron capture. The inset shows a rich part of the spectrum $(\mathrm{m} / \mathrm{z}$ 900-980) magnified. (b) SORI-CID spectrum of [M + $3 \mathrm{H}]^{3+}$ ions. (c) SORI-CID spectrum of lacticin $481[\mathrm{M}+4 \mathrm{H}]^{2+}$ ions formed by double electron capture. The inset shows the loss of an $\mathrm{H}^{\bullet}$ radical from the parent ion. Noise peaks are marked with asterisks. 
loss of $33 \mathrm{Da}$, like in the SORI-CID spectra of [M+ $3 \mathrm{H}]^{2+}$ and $[\mathrm{M}+4 \mathrm{H}]^{3+\bullet}$ ions, where it is the most abundant fragmentation. However, minor $\mathrm{H}^{\bullet}$ loss from $[\mathrm{M}+4 \mathrm{H}]^{2+}$ ions was observed leading to the formation of radical $[\mathrm{M}+3 \mathrm{H}]^{2+}$ ions.

\section{Discussion}

Although nondissociative single and double electron capture is often observed in ECD of multiply protonated peptide ions, it is usually not very abundant. In contrast, lacticin 481 does not only exhibit single electron capture but also abundant double electron capture. The predominant SORI-CID fragmentation channel observed for the radical $[\mathrm{M}+3 \mathrm{H}]^{2+}$ ions and $[\mathrm{M}+4 \mathrm{H}]^{3+} \bullet^{\bullet}$ ions is $\mathrm{SH}^{\bullet}$ loss. This $\mathrm{SH}^{\bullet}$ loss can be explained by assuming that the radical site, induced by the captured electron, relocates to near a sulfur atom of one of the lanthionine bridges resulting in $\mathrm{S}-\mathrm{C}$ bond cleavage. The selectivity for this $\mathrm{S}-\mathrm{C}$ bond cleavage after electron capture is supported by our earlier research on ECD of other lantibioticsä[5]ändätheoreticallyäpredictedätoäoccurän ECDäbyäTurecekäetäal.ä[19]äTheäsecondäS-Cäbond cleavage, needed for $\mathrm{SH}^{\bullet}$ loss, has to be induced by collisional activation with argon because $\mathrm{SH}^{\bullet}$ loss is absent in the ECD spectra of lacticin $481[\mathrm{M}+4 \mathrm{H}]^{4+}$ and $[\mathrm{M}+3 \mathrm{H}]^{3+}$ ions. Interestingly, a study performed on the much smaller distonic radical ion of a thioether, namely ${ }^{\circ} \mathrm{CH}_{2}-\mathrm{CH}_{2}-\mathrm{S}-\mathrm{CH}_{2}^{+}$revealed that thisäisäaästableäspeciesäinätheägas-phaseä[30].äCID spectra of this distonic radical ion are dominated by $\mathrm{CH}_{2} \mathrm{~S}^{+}$ions resulting from cleavage of an $\mathrm{S}-\mathrm{C}$ bond. Thus, also in CID of this small but related distonic ion the S-C bond is cleaved. Furthermore, the described $\mathrm{S}-\mathrm{C}$ bond cleavage involves a mobile radicaläsiteä[30].äAlsoäinäECDämobileäradicaläsitesäcan play a role because radical site initiated secondary cleavages are observed after capture of only one electronä[31].äAäminoräCIDäfragmentationächanneläof - $\mathrm{CH}_{2}-\mathrm{CH}_{2}-\mathrm{S}-\mathrm{CH}_{2}^{+}$distonic ions is the elimination of $\mathrm{SH}^{*}$. This means that even two $\mathrm{S}-\mathrm{C}$ bond cleavages can take place in these distonic ions by collisional activation. A theoretical study performed on the same distonic radical ion was in good agreement with the earlierämentionedäexperimentaläresultsä[32].

If abundant stable biradicals would have been formed by double electron capture of $[\mathrm{M}+4 \mathrm{H}]^{4+}$ ions, we would expect to see extensive collision induced $\mathrm{SH}^{\bullet}$ losses from these $[\mathrm{M}+4 \mathrm{H}]^{2+}$ ions as this was the most important fragmentation channel of the monoradical species. There are remarkable differences between the SORI-CID spectra of $[\mathrm{M}+4 \mathrm{H}]^{2+}$ ions and those of the radical $[\mathrm{M}+3 \mathrm{H}]^{2+}$ ions and $[\mathrm{M}+4 \mathrm{H}]^{3+}$ ions. However, the absence of $\mathrm{SH}^{\bullet}$ loss in the SORI-CID spectra of $[\mathrm{M}+4 \mathrm{H}]^{2+}$ ions is especially striking, and this could indicate that there are hardly any free radical sites in these ions. Because of the absence of $\mathrm{SH}^{\bullet}$ loss, we believe that the two unpaired electrons must have recombined to form two-electron bonds. One possibility is that two $\mathrm{S}^{\bullet}$ termini, also called thiyl radicals, recombine to a disulfide bond. This is an exothermic reaction thatäreleasesäaboutà2.2äeVänergyä[33].äAänewlyäformed bond would change the structural characteristics of the lacticin 481 ions. The absence of $b_{26}^{3+}$ ions in the SORICID spectra of $[\mathrm{M}+4 \mathrm{H}]^{2+}$ ions, which are present in the SORI-CID spectra of $[\mathrm{M}+3 \mathrm{H}]^{3+}$ ions, might point at such a structural change in the C-terminal part of the lacticin 481 ions. The reason for this structural change is a matter of speculation, but it may be that the Cterminal lanthionine bridge opened because of a captured electron and then recombined with another radical site. The remainder of the SORI-CID fragments of the $[\mathrm{M}+4 \mathrm{H}]^{2+}$ ions were in good agreement with those of the $[\mathrm{M}+3 \mathrm{H}]^{3+}$ ions and thus with a nonradical cation. This leads us to the conclusion that most of the $[\mathrm{M}+4 \mathrm{H}]^{2+}$ ions must have recombined their two unpaired electrons. We say most of the $[\mathrm{M}+4 \mathrm{H}]^{2+}$ ions, because $\mathrm{H}^{\bullet}$ radical loss from $[\mathrm{M}+4 \mathrm{H}]^{2+}$ ions was alsoäobservedätoäsomeäextentä(insetäFigureä3c).äThe intensity of the peaks corresponding to $[\mathrm{M}+3 \mathrm{H}]^{2+}$ ions was $\sim 25 \%$ of the peaks corresponding to the parent ions $\left([\mathrm{M}+4 \mathrm{H}]^{2+}\right.$ ions). This indicates that at least a part of the ion population exhibits a structure containing two separate radical sites instead of a recombined chemical bond. However, because of the absence of $\mathrm{SH}^{\bullet}$ loss in the SORI-CID spectra of $[\mathrm{M}+4 \mathrm{H}]^{2+}$ ions, we propose that these radical sites are not close to lanthionine bridges. This also implies that the initial diradical ion population is heterogeneous. Apparently there are other sites in lacticin 481 where stable radicals

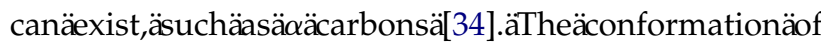
the diradical ions is very important for bringing two radical sites in a reactive configuration. If the radical sites are not mobile, the rate of conformational changes and thermal structure fluctuations would be the limiting factors in the rate of radical recombination into two-electron bonds. Conformational changes and thermal motions take place on time scales about hundreds ofämicrosecondsätoäsecondsä[35]äandäareäslowäinäcomparison with the actual radical recombination processes. The fact that not all the biradicals have recombined their radical sites would then be a matter of stericalähindrance.äLeymarieätäl.å31]ähaveähownähat the radical sites induced by electron capture can be mobile and can initiate a radical cascade. However, the radicals formed in lacticin 481 leading to $\mathrm{H}^{\bullet}$ loss do not seem to be very mobile because of their long lifetime. Our main question was: will two captured electrons in protonated lacticin 481 ions form two separate radical sites or will they recombine to form a new chemical bond? We find that after several seconds, i.e., the time scale of our experiments, most of $[\mathrm{M}+4 \mathrm{H}]^{4+}$ ions that have captured two electrons have become $[\mathrm{M}+4 \mathrm{H}]^{2+}$ ions through radical recombination and a substantially smaller number of ions are still $[\mathrm{M}+4 \mathrm{H}]^{2+2 \bullet}$ biradical ions. 


\section{Conclusions}

The most important observations from the experiments described in this article were the resemblance of the SORI-CID spectra of the $[\mathrm{M}+3 \mathrm{H}]^{3+}$ ions and the $[\mathrm{M}+$ $4 \mathrm{H}]^{2+}$ ions of lacticin 481 and the large differences between the SORI-CID spectra of $[\mathrm{M}+4 \mathrm{H}]^{3+} \boldsymbol{\bullet}^{\text {ions and }}$ $[\mathrm{M}+4 \mathrm{H}]^{2+}$ ions. This led to the conclusion that most of the ions formed by double electron capture must have recombined their two unpaired electrons. However, the fact that some $[\mathrm{M}+4 \mathrm{H}]^{2+}$ ions are able to lose a $\mathrm{H}^{\bullet}$ radical, points to the existence of two separated radical sites in at least part of ions formed by double electron capture. We could, therefore, refer to these ions as biradicals or $[\mathrm{M}+4 \mathrm{H}]^{2+2}$ ions. In the SORI-CID spectra of the radical $[\mathrm{M}+3 \mathrm{H}]^{2+}$ and $[\mathrm{M}+4 \mathrm{H}]^{3+} \cdot$ ions very intense $\mathrm{SH}^{\bullet}$ losses are present. This specificity further validates the strong involvement of lanthionine bridges in electron capture dissociation processes.

\section{Acknowledgments}

Lacticin 481 was kindly provided by Eefjan Breukink, Department of Biochemistry of Membranes, Utrecht University. This work is part of research program 49 for mass spectrometric imaging and structural analysis of biomacromolecules of the Foundation for Fundamental Research of Matter (FOM), which is financially supported by the Netherlands Organization for Scientific Research (NWO). This project is financially supported by FOM under project FOM-00PR1950 and the Bijvoet Center for Biomolecular Research.

\section{References}

1. Breukink, E.; Wiedemann, I.; van Kraaij, C.; Kuipers, O. P.; Sahl, H.; de Kruijff, B. Science 1999, 286, 2361-2364.

2. Edman, P.; Begg, G. Eur. J. Biochem. 1967, 1, 80-81.

3. Kellersberger, K. A.; Fabris, D. Proceedings of the 52nd ASMS Conference on Mass Spectrometry and Allied Topics, Nashoille, TN, 2004.

4. Meyer, H. E.; Heber, M.; Eisermann, B.; Korte, H.; Metzger, J. W.; Jung, G. Anal. Biochem. 1994, 223, 185-190.

5. Kleinnijenhuis, A. J.; Duursma, M. C.; Breukink, E.; Heeren, R. M. A.; Heck, A. J. R. Anal. Chem. 2003, 75, 3219-3225.

6. Zubarev, R. A.; Kelleher, N. L.; McLafferty, F. W. J. Am. Chem. Soc. 1998, 120, 3265-3266.

7. Zubarev, R. A.; Kruger, N. A.; Fridriksson, E. K.; Lewis, M. A.; Horn, D. M.; Carpenter, B. K.; McLafferty, F. W. J. Am. Chem. Soc. 1999, 121, 2857-2862.

8. Zubarev, R. A.; Haselmann, K. F.; Budnik, B. A.; Kjeldsen, F.; Jensen, F. Eur. J. Mass Spectrom. 2002, 8, 337-349.

9. Cerda, B. A.; Horn, D. M.; Breuker, K.; Carpenter, B. K.; McLafferty, F. W. Eur. J. Mass Spectrom. 1999, 5, 335-338.
10. Roepstorff, P.; Fohlman, J. Biomed. Mass Spectrom. 1984, 11, 601.

11. Guan, Z.; Yates, N. A.; Bakhtiar, R. J. Am. Soc. Mass Spectrom. 2003, 14, 605-613.

12. Mirgorodskaya, E.; Roepstorff, P.; Zubarev, R. A. Anal. Chem. 1999, 71, 4431-4436.

13. Hakansson, K.; Cooper, H. J.; Emmett, M. R.; Costello, C. E.; Marshall, A. G.; Nilsson, C. L. Anal. Chem. 2001, 73, 4530-4536.

14. Stensballe, A.; Jensen, O. N.; Olsen, J. V.; Haselmann, K. F.; Zubarev, R. A. Rapid Commun. Mass Spectrom. 2000, 14, 17931800.

15. Kelleher, N. L.; Zubarev, R. A.; Bush, K.; Furie, B.; Furie, B. C.; McLafferty, F. W.; Walsh, C. T. Anal. Chem. 1999, 71, 42504253.

16. Mirgorodskaya, O. A.; Haselmann, K. F.; Kjeldsen, F.; Zubarev, R. A. Eur. J. Mass Spectrom. 2003, 9, 139-148.

17. Zubarev, R. A. Mass Spectrom. Rev. 2003, 22, 57-77.

18. Uggerud, E. Int. J. Mass Spectrom. 2004, 234, 45-50.

19. Turecek, F.; Polasek, M.; Frank, A. J.; Sadilek, M. J. Am. Chem. Soc. 2000, 122, 2361-2370.

20. Syrstad, E. A.; Turecek, F. J. Am. Soc. Mass Spectrom. 2005, 16, 208-224.

21. Kruger, N. A.; Zubarev, R. A.; Horn, D. M.; McLafferty, F. W. Int. J. Mass Spectrom. 1999, 185/186/187, 787-793.

22. Horn, D. M.; Ge, Y.; McLafferty, F. W. Anal. Chem. 2000, 72, $4778-4784$.

23. van den Hooven, H. W.; Lagerwerf, F. M.; Heerma, W.; Haverkamp, J.; Piard, J.; Hilbers, C. W.; Siezen, R. J.; Kuipers, O. P.; Rollema, H. S. FEBS Lett. 1996, 391, 317-322.

24. Gauthier, J. W.; Trautman, T. R.; Jacobson, D. B. Anal. Chim. Acta 1991, 246, 211-225.

25. Heck, A. J. R.; de Koning, L. J.; Pinkse, F. A.; Nibbering, N. M. M. Rapid Commun. Mass Spectrom. 1991, 5, 406-414.

26. Mize, T. H.; Taban, I.; Duursma, M.; Seynen, M.; Konijnenburg, M.; Vijftigschild, A.; Doornik, C. V.; Rooij, G. V.; Heeren, R. M. A. Int. J. Mass Spectrom. 2004, 235, 243-253.

27. Cooper, H. J.; Hakansson, K.; Marshall, A. G.; Hudgins, R. R.; Haselmann, K. F.; Kjeldsen, F.; Budnik, B. A.; Polfer, N. C.; Zubarev, R. A. Eur. J. Mass Spectrom. 2003, 9, 221-222.

28. Haselmann, K. F.; Budnik, B. A.; Kjeldsen, F.; Polfer, N. C.; Zubarev, R. A. Eur. J. Mass Spectrom. 2002, 8, 461-469.

29. Cooper, H. J.; Hudgins, R. R.; Hakansson, K.; Marshall, A. G. J. Am. Soc. Mass Spectrom. 2002, 13, 241-249.

30. Polce, M. J.; Wesdemiotis, C. Rapid Commun. Mass Spectrom. 1996, 10, 235-241.

31. Leymarie, N.; Costello, C. E.; O'Connor, P. B. J. Am. Chem. Soc. 2003, 125, 8949-8958.

32. Lee, H.-L.; Li, W.-K.; Chiu, S.-W. J. Mol. Struct. Theochem. 2003, $629,237-250$

33. Sawicka, A.; Skurski, P.; Hudgins, R. R.; Simons, J. J. Phys. Chem. B 2003, 107, 13505-13511.

34. Rauk, A.; Yu, D.; Taylor, J.; Shustov, G. V.; Block, D. A.; Armstrong, D. A. Biochemistry 1999, 38, 9089-9096.

35. Yang, H.; Luo, G.; Karnchanaphanurach, P.; Louie, T.-M.; Rech, I.; Cova, S.; Xun, L.; Sunney Xie, X. Science 1996, 302, 262-266. 